\title{
Further evidence on efficiency of Bahrain Bourse: A high challenge for other industries
}

DOI: $10.35530 / 1 T .071 .05 .1732$

Further evidence on efficiency of Bahrain Bourse: A high challenge for other industries

The purpose of the present study is to provide further evidence of the weak form efficiency of the Bahrain Bourse. The research methodology is based on daily closing index values of the Bahrain Bourse from 2011 to 2015 in order to test the efficiency of the stock market while runs test, Autocorrelation Function, and advance tools such as ARCH and GARCH models and Hurst Index to provide further evidence of the weak form efficiency of the Bahrain stock market. For instance, a volatile and inefficient stock market has a negative impact on textile and apparel industry in the Kingdom of Bahrain, which is one of the most prosperous and attractive industries in the country. The empirical results revealed that Bahrain stock market does not follow normal distribution and the successive price changes are not independent. Further, ARCH effect is significant and indicative of a time-varying conditional volatility. There is an arbitrage opportunity and extreme mispricing in the Bahrain stock market as indicated by the GARCH $(1,1)$ model. The results of the Hurst exponent also confirm the inefficiency of the market. The results of these tests are consistent indicating that the Bahrain stock market is inefficient.

Keywords: Efficient Market Hypothesis (EMH), ARCH effect, GARCH models, Hurst Index

\section{Cercetări empirice extinse privind eficiența piețelor bursiere din Bahrain: 0 provocare majoră pentru celelalte industrii}

Scopul prezentului studiu de cercetare este de a oferi dovezi suplimentare despre eficiența slabă a Bursei din Bahrain. Metodologia de cercetare se bazează pe valorile zilnice de închidere ale indicelui bursier principal al Bursei din Bahrain din 2011 până în 2015 pentru a testa eficiența pieței bursiere. În acest sens se aplică anumite teste, funcția de autocorelare și instrumente avansate precum modelele ARCH și GARCH, dar și indicele Hurst pentru a furniza în continuare dovada eficienței slabe a pieței bursiere din Bahrain. De exemplu, o piață bursieră volatilă și ineficientă are un impact negativ asupra industriei textile și de îmbrăcăminte din Bahrain, care reprezintă una dintre cele mai prospere și atractive industrii din țară. Rezultatele empirice au arătat că piața bursieră din Bahrain nu urmează distribuția normală, iar modificările succesive ale prețurilor nu sunt independente. În plus, efectul ARCH este semnificativ și indică o volatilitate condițională care variază în timp. Există o oportunitate de arbitraj și anomalii extreme privind prețurile pe piața bursieră din Bahrain, după cum indică modelul GARCH (1,1). Rezultatele empirice privind indicele Hurst confirmă, de asemenea, ineficiența pieței. Rezultatele acestor teste sunt consistente, indicând faptul că piața bursieră din Bahrain este ineficientă.

Cuvinte-cheie: ipoteza piețelor eficiente (EMH), efectul $A R C H$, modele $G A R C H$, indicele Hurst

\section{INTRODUCTION}

The Efficient Market Hypothesis (EMH) is a fundamental theory in finance. The EMH relates to how quickly and accurately the market reacts to new information that enters the market through economic reports, company announcements, political statements, or public surveys. If the market is informationally efficient then security prices adjust rapidly and accurately to new information. According to this hypothesis, security prices reflect fully all the information that is available in the market. Since all the information is already incorporated in prices, a trader is not able to make any excess returns. Thus, $\mathrm{EMH}$ puts forth that it is not possible to outperform the market through market timing or stock selection. The efficiency of Bahrain stock market represents a high challenge for other industries. For instance, textile and apparel producers play a very important role in the Kingdom of Bahrain since this industry has significant growth potential. This complex topic will be considered for a future extensive research study. The origins of the EMH can be traced to Bachelier's doctoral thesis "Theory of Speculation" in 1900 and seminal paper titled 'Proof That Properly Anticipated Prices Fluctuate Randomly' by Nobel Laureate Paul Samuelson in 1965 [1]. However, it was Eugene Fama who coined the term EMH in 1970. He advocated that in efficient market, securities prices fully reflect all the information. If capital markets are efficient, investors cannot expect to achieve superior 
profits by adopting a certain trading strategy. According to Fama [2], there are three forms of efficiency, i.e. weak form, semi-strong form and strong form. First, EMH in its weak form states that all information impounded in the past price of a stock is fully reflected in current price of the stock. Therefore, information about recent or past trend in stock prices is of no use in forecasting future price. Undoubtedly, it rules out the use of technical analysis in predicting future prices of securities. The semi-strong form takes the information set one step further and includes all publicly available information. There is plethora of information of potential interest to investors. Besides past stock prices, information such as announcement of earnings, bonus, dividends, mergers and acquisitions, change of CEO and so on are available through annual reports, economic reports, brokerage firm recommendations, and investment advisory letters.

According to the semi-strong form of the $E M H$, analysing annual reports or other published data with a view to make profit in excess is not possible because market prices had already adjusted to any good or bad news contained in such reports as soon as they were revealed. The EMH in its strong form states that current market price reflects all - both public and private information and even insiders would find it impossible to earn abnormal returns in the stock market. In his work, Fama, sustained the existence of the efficiency of the markets at least in weak form, affirming that the market is a martingale, since the good respect of the price of the title to the time $t+1$ is the price of the same to the time $t$. A martingale is a sequence of random variables for which, at a particular time in the realized sequence, the expectation of the next value in the sequence is equal to the present observed value even given knowledge of all prior observed values. If $S_{t}$ (stock price) is a stochastic process, $F$ is a is a filtration of the underlying probability space and for each $t S_{t}$ is measurable in $F_{t}: \mathrm{E}\left(\boldsymbol{S}_{t+1} \mid \boldsymbol{F}_{t}\right)=S_{t}$; where $\mathrm{E}\left(\boldsymbol{S}_{t+1} \mid \boldsymbol{F}_{t}\right)$ is the conditional expectation. Although financial literature supports the theory of market efficiency, in reality the market is not perfectly efficient. Anomalies do exist and there are investors and traders who outperform the market. The EMH thus has very important implications for both investors and authorities that regulate and control the market.

\section{LITERATURE REVIEW}

In the literature, due to the huge implications of the $\mathrm{EMH}$, the operations of financial markets is still constantly been examined by the academicians and practitioners. Over a period of time a number of researchers have examined the existence of the $\mathrm{EMH}$ theory in various developed and undeveloped markets with varying results [3, 4]. Chan et al. [5] analyzed the weak form hypothesis in Hong Kong, South Korea, Singapore, Taiwan, Japan, and the United States [4]. Their findings indicate that stock prices in these major Asian markets and the United
States are efficient in the weak form. Lo and MacKinlay [6] use a variance ratio test to analyze the weekly returns of both the equally weighted and value weighted CRSP indices and find that stock prices do not follow a random walk. Iqbal and Mallikarjunappa [7, 8] studied Indian stock market and found that Indian stock market is not efficient in weak and semi-strong form. Dahel and Laabas [9] investigated the efficiency of Bahrain, Kuwait, Saudi Arabia and Oman belonging to Gulf Cooperation Council equity markets. They investigated the observations from year 1994 to 1998 . They concluded that the stock market of Kuwait is strongly in support of weak form of efficiency and other markets reject the weak form of the EMH. The reason seems to be the strong market characteristics of the Kuwait in comparison to the other three markets.

The empirical findings of Abeysekera [10] and Abraham et al. [11] reject the hypothesis of weak form efficiency for stock markets in Sri Lanka, Bahrain Kuwait, and Saudi Arabia. Rao and Shankaraiah [12] investigated the stock market efficiency and endeavoured to develop strategies for Gulf Co-operation Council (GCC) stock markets. They concluded that these markets were neither developed nor informationally efficient and recommended that apart from better networking, co-operation and the creation of investor awareness, the simultaneous listing of GCC countries to reduce the thin trading problem need to be implemented. Moustafa [13] examined the weak form efficiency of United Arab Emirates (UAE) stock market by observing the behaviour of stock prices. The result of UAE stock market showed weak form efficiency. Sharma [14] in his study, tested whether daily returns series of Gulf Co-operation Council (GCC) stock markets are an approximation of normal distribution or not. Saudi, Qatar, Kuwait, and Oman stock market indices were examined by him in his study. Chi-square, Kolmogorov-Smirnov test, Autocorrelation Function and Partial Autocorrelation Functions were applied to test for randomness. The results revealed that the distribution of daily returns on these markets significantly deviated from the normal distribution during the study period.

Elango and Hussein [15] examined market efficiency across the seven stock markets in the GCC countries. Using daily indices data from October 2001 to October 2006 and Kolmogorov-Smirnov test, they reject the null hypothesis that the returns follow a normal distribution for all the seven markets. Again, based on runs test for randomness, they find that the hypothesis pertaining to random walk and weak-form efficiency of the GCC markets is rejected for all the seven markets during the study period. Smith [16] conducted research for weak form Efficient Market Hypothesis in five Middle East stock markets by applying multiple variance ratio test to the data. For Israeli, Lebanese and Jordanian markets followed the random walk, while stock markets of Kuwait, and Oman random walk hypothesis were rejected. Asiri [17] measured the performance of the Bahrain Stock 
Exchange (BSE) by applying the Dickey Fuller unit root tests, the ARIMA model, and exponential smoothing techniques. The results showed evidence that stock returns followed a random walk process with no drift and trend.

Al Kharusi and Weagley [18] studied the Weak form efficiency in Muscat Securities Market from 2007 to 2011 by using the daily stock indices. The parametric test of serial correlations was used and rejected the Efficient market hypothesis by researchers in all the three periods of pre-crisis during crisis and post crisis in Muscat Securities Market. Awan and Subayyal [19] studied six Stock Exchanges in Gulf (Oman, UAE, Kuwait, Saudi Arabia, Bahrain and Qatar) for the period 2011 to 2015. The results of the Auto Correlation and Runs test provide evidence that the stock prices in all the Gulf Markets are not following the random walk model and the significant auto correlation coefficient at different lags has rejected the null hypothesis of that the market is efficient in its weak form. In order to test the efficiency at the weak-form several statistical techniques have been used such as runs test, unit root test, and autocorrelation tests. Sharma and Kennedy [20], Karemera et al. [21] and Abraham et al. [11] adopted run test, while Mookerjee and Yu [22], Groenwold et al. [23] and Seddighi and Nian [24] conducted both run test and unit root test in their studies. Volatility in the stock market of the developed markets has been studied extensively. The seminal work of Engle [25] on Autoregressive Conditional Heteroscedasticity $(A R C H)$ model on UK inflation data and its Generalized form GARCH (Generalized $A R C H$ ) by Bollerslev [26] have led to using these models to form the characteristics of financial time series.

\section{DATA AND METHODOLOGY}

There are very few studies that have made an attempt to test the efficiency of the Bahrain stock market. Gharaibeh and Hammadi [27] tested the day of the week effect, Hawaldar [28] empirically tested the capital asset pricing on Bahrain Bourse. Hawaldar [29] studied the reaction of Bahrain Bourse to announcement of annual financial results. Hawaldar [29] examined the cross-sectional variation of portfolio returns. Hawaldar et al. [30] investigated the month of the year effect on selected commercial banks and service sector companies listed on the Bahrain Bourse. Asiri [17] applied the Dickey Fuller unit root tests, the ARIMA model and exponential smoothing techniques to measure the performance of Bahrain Stock Market. This study attempts to study the weak form of efficiency of the Bahrain stock market using statistical tools such as the runs test, autocorrelation function, ARCH effect test and $\mathrm{GARCH}$ $(1,1)$ model, in the last part we add the estimation the Hurst Index through the R/S method. The present study is unique as it examines the volatility in Bahrain stock market by using the ARCH and GARCH $(1,1)$ model. ARCH Effect and GARCH $(1,1)$ tests are employed to examine the weak form efficiency of
Bahrain stock market. In the last part we introduced the estimation of the Hurst Index. Through the index, it is possible to measure the market's efficiency. According to the financial literature, if the market is efficient, the price variations follow a Brownian Geometric motion $(\mathrm{BGm})$ with $\mathrm{H}=0.5$, when the index is different form 0.5 the market loses the efficiency and theoretically is possible to beat it. Hurst index gives an idea of how the price increments are related (negatively or positively). Besides Runs test and Autocorrelation function, the study uses advance tools such as $\mathrm{ARCH}, \mathrm{GARCH}$ models and Hurst Index to provide further evidence of the weak form efficiency of the Bahrain bourse.

\section{Objectives of the study}

- To analyse if observed price series follow normal distribution;

- To examine if share price movements are independent and random;

- To examine the autocorrelation of observed price series;

- To investigate the volatility clustering of the observed price series;

- To examine if the price variation follows a Geometric Brownian motion (GBm) (are randomly or there is a persistence/anti-persistence in the time series).

\section{Hypotheses of the study}

$\mathrm{H}_{1}$ : Successive price changes are independent and move randomly;

$\mathrm{H}_{2}$ : There is white noise effect;

$\mathrm{H}_{3}$ : There is no autocorrelation in price series;

$\mathrm{H}_{4}$ : The exogenous variable in the mean equation for $\mathrm{GARCH}$ model is insignificantly different from zero;

$\mathrm{H}_{5}$ : There is non-volatility clustering in the observed price series;

$\mathrm{H}_{6}$ : The estimation of the Hurst Index.

\section{Research methodology}

The data used for the study is the daily closing index of the Bahrain Bourse from 2011 to 2015 . To test the weak form of market efficiency, several methodologies are available. They include Runs test, $\mathrm{ARCH}$ effect, GARCH $(1,1)$ model and the Autocorrelation Function.

Runs Test

Runs test is used to analyze the serial independence of the observed price series. The runs test is calculatedby using the following formula:

$$
\mu=\frac{2 n_{1} n_{2}}{n_{1}+n_{2}}+1
$$

where $\mu$ is the mean number of runs, $n_{1}$ - number of positive runs, $n_{2}$ - number of negative runs.

The variance of the expected number of runs can be calculated by using following formula:

$$
\sigma^{2}=\frac{2 n_{1} n_{2}\left(2 n_{1} n_{2}-n_{1}-n_{2}\right)}{\left(n_{1}+n_{2}\right)^{2}\left(n_{1}+n_{2}-1\right)}
$$


The standard normal Z-statistic used to conduct a run test is given by:

$$
Z=\frac{r-\mu}{\sigma^{2}}
$$

where $r$ is the number of runs (actual sequence of counts).

Autocorrelation Function

Autocorrelation is defined as a mathematical representation of the degree of similarity between a given time series and a lagged version of itself over successive time intervals. The Ljung - Box $Q$ - statistic and their $p$ values are used in the study to test the null hypothesis that there is no autocorrelation up to order $k$ and is computed as:

$$
\begin{gathered}
\tau_{k}=\left[\sum_{t=k+1}^{T}\left(\left(Y_{t}-\bar{Y}\right)\left(Y_{t-k}\right)\right) /(T-K)\right] /\left[\sum_{t=1}^{T} \frac{\left(Y_{t}-\bar{Y}\right)^{2}}{T}\right] \\
Q_{L B}=T(T+2) \sum_{j=1}^{k} \frac{r_{j}^{2}}{T-j}
\end{gathered}
$$

where $r_{j}$ is the $j^{\text {th }}$ autocorrelation and $T$ - the number of observations.

\section{ARCH model}

The Arch effect has its roots in time varying conditional volatility, so:

$$
\sigma_{t}^{2}=\sum\left(X_{t}-\bar{X}\right)^{2}
$$

where $\sigma_{t}^{2}$ is the conditional variance and $\bar{X}-$ conditional mean.

The ARCH models are based on the following formula:

$$
h_{t}=w+\alpha_{1} \varepsilon_{t}^{2}+\alpha_{2} \varepsilon_{t-1}^{2}+\ldots+\alpha_{p} \varepsilon_{t-p}^{2}
$$

where $h_{\mathrm{t}}$ is the conditional variance.

The LM-ARCH test has:

$$
\left\{\begin{array}{l}
H_{0}: \text { coefficients }=0 \\
H_{1}: \text { heteroskedasticity }
\end{array}\right.
$$

where $T R^{2} \sim \chi^{2}$ is the statistic used, the test is constructed by regressing the squared residual on $p$ past values.

\section{GARCH $(1,1)$ model}

Under the GARCH model, the forecasts of time-varying variance depend on the lagged variance of any asset. This model is estimated on two specifications, that is, the conditional mean equation and conditional variance equation.

The basic $\operatorname{GARCH}(1,1)$ is expressed as:

$$
\begin{gathered}
r_{t}=\mu+\phi r_{t-1}+\epsilon_{t} \\
\left.\epsilon_{t}\right|_{\phi_{t-1}} \sim N\left(0, h_{t}\right) \\
h_{t}=k+\alpha \epsilon_{t-1}^{2}+\beta h_{t-1}
\end{gathered}
$$

where $\alpha+\beta$ measures the volatility clustering, equation 9 is the conditional mean equation and equation 11 is the conditional variance equation. In the mean equation, the exogenous variable $\phi$ should be insignificantly different from zero, that is, $\phi=0$ to accept weak-form market efficiency. If the value of $\alpha+\beta$ is close to 1 it is assumed that there is a high-persistence volatility clustering, and this indicates market inefficiency.

The following table presents the descriptive statistics for the Bahrain Index for the period 2011 to 2015. The descriptive statistics presents the distribution of observed price series. It can be observed that the frequency distribution for all the years is not normal. A distribution is normally distributed if the skewness is 0 and the kurtosis is 3 . The results show that the

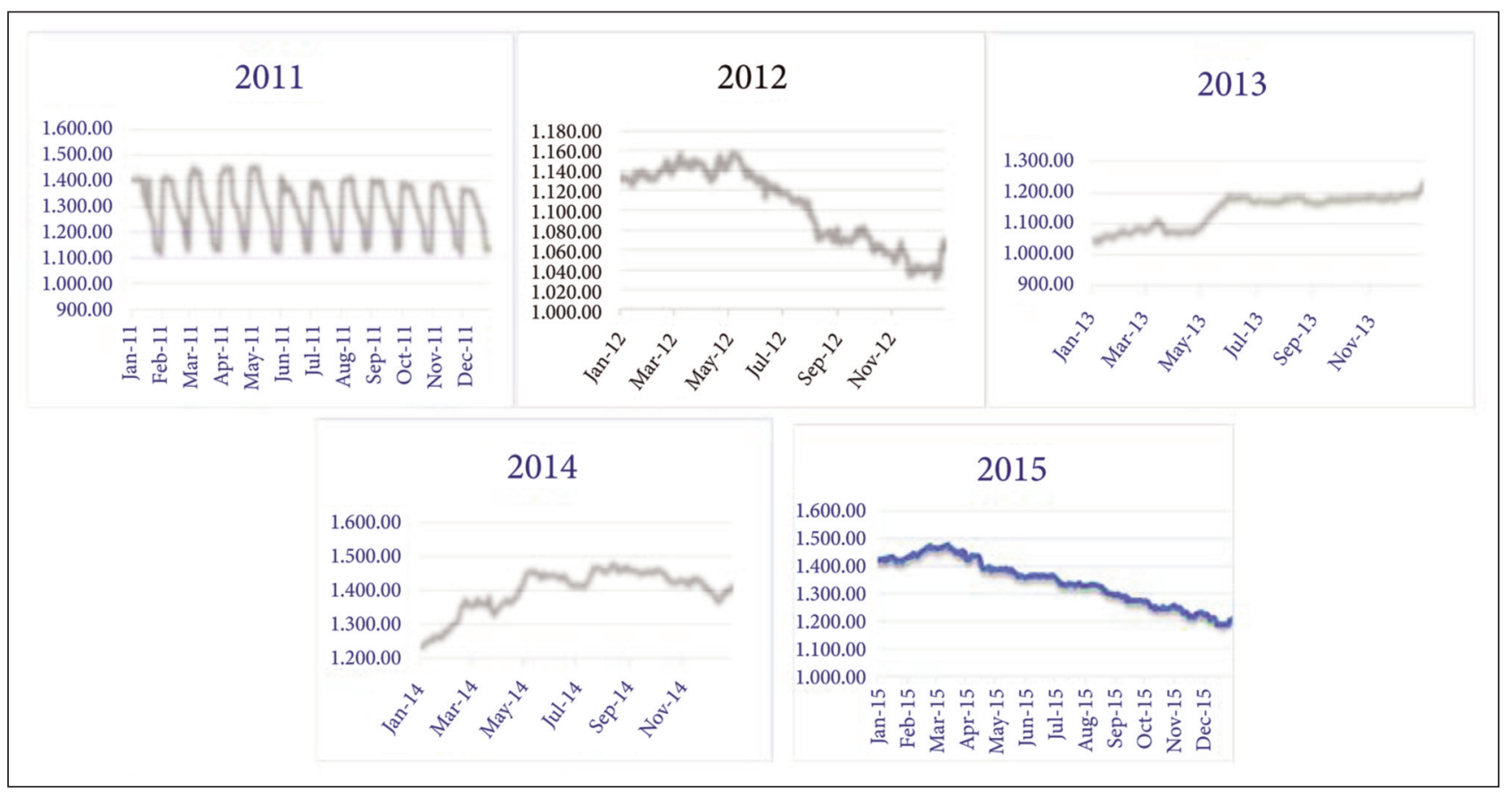

Fig. 1. The trend of Bahrain Index for the period from 2011 to 2015 
values of skewness and kurtosis are not 0 and 3 for all the years. Thus, it can be inferred that the observed values are not normally distributed, and the distribution does not follow random walk. The trend in the mean values shows fluctuations in the movement of the index. The average index level was 1313.23 in 2011. The level dipped in 2012. In 2013, the index raised marginally while in 2014 it reached a peak of 1414.83. The index could not sustain this rise leading to a decline in 2015 . The standard deviation of the index is the highest in 2011 at 107.65 signalling high volatility. The year 2012 records a low standard deviation of 38.44 indicating stability in the index.
The above table depicts the output of the runs test for the years 2011 to 2015 . Runs test is used to find the serial independence of the observed prices. If the succeeding price variation is independent to each other, the market is said to be efficient. The p-values of the runs test clearly show that the successive price series for all the years are statistically significant at $5 \%$ level of significance. The null hypothesis, i.e., the succeeding price changes are independent and move randomly is rejected. Hence the study concludes that the successive price changes are not independent. This indicates that the market is inefficient. Thus, the Bahrain market does not exhibit weak form efficiency. The results show that the investors can predict the market returns based on historical information Table 3 shows that $p$-value is less than 0.05 level of significance, hence the study rejects the null hypothesis and concludes that there is no white noise effect for the years from 2011 to 2015.

Table 4 presents the results of the ARCH test. The $p$ value is less than 0.05 , the level of significance for all the years. The $\mathrm{ARCH}$ effect is significant and indicative of a time -varying conditional volatility and, as a result, the presence of a fattailed distribution (i.e. excess kurtosis $>0$. Autoregressive

Table 2

\begin{tabular}{|c|c|c|c|c|c|c|c|c|c|c|}
\hline \multicolumn{10}{|c|}{ RUNS TEST } \\
\hline Year & Mean & $\mathbf{R}$ & $\mathbf{n}_{\mathbf{0}}$ & $\mathbf{n}_{\mathbf{1}}$ & $\mathbf{n}$ & $\mathbf{E}(\mathbf{R})$ & $\mathbf{V a r}(\mathbf{R})$ & $\mathbf{S t D e v}(\mathbf{R})$ & $\mathbf{Z}$ & $\mathbf{p}$-value \\
\hline 2011 & 1313.23 & 24 & 106 & 139 & 245 & 121.278 & 58.797 & 7.668 & -12.686 & $0.000^{*}$ \\
\hline 2012 & 1110.03 & 4 & 104 & 144 & 248 & 121.774 & 58.565 & 7.653 & -15.390 & $0.000^{*}$ \\
\hline 2013 & 1156.93 & 2 & 95 & 152 & 247 & 117.923 & 55.098 & 7.423 & -15.617 & $0.000^{*}$ \\
\hline 2014 & 1414.83 & 6 & 93 & 154 & 247 & 116.968 & 54.197 & 7.362 & -15.073 & $0.000^{*}$ \\
\hline 2015 & 1346.97 & 2 & 117 & 128 & 245 & 123.253 & 60.752 & 7.794 & -15.556 & $0.000^{*}$ \\
\hline
\end{tabular}

Note: * $95 \%$ level of significance

Table 3

\begin{tabular}{|c|c|c|c|c|}
\hline \multicolumn{5}{|c|}{ WHITE-NOISE TEST } \\
\hline Year & Score & C.V. & P-value & $\mathbf{5 \%}$ \\
\hline 2011 & 161.03 & 3.84 & 0.000 & FALSE \\
\hline 2012 & 245.82 & 3.84 & 0.000 & FALSE \\
\hline 2013 & 241.12 & 3.84 & 0.000 & FALSE \\
\hline 2014 & 240.15 & 3.84 & 0.000 & FALSE \\
\hline 2015 & 243.54 & 3.84 & 0.000 & FALSE \\
\hline
\end{tabular}

Note: * $\mathrm{P}$-value is less than $5 \%$ we can reject the null hypothesis, there is no white-noise effect
ARCH EFFECT TEST

\begin{tabular}{|c|c|c|c|c|}
\hline \multicolumn{5}{|c|}{ ARCH EFFECT TEST } \\
\hline Year & Score & C.V. & P-Value & $\mathbf{5} \%$ \\
\hline 2011 & 162.02 & 3.84 & 0.000 & TRUE \\
\hline 2012 & 245.82 & 3.84 & 0.000 & TRUE \\
\hline 2013 & 240.94 & 3.84 & 0.000 & TRUE \\
\hline 2014 & 240.44 & 3.84 & 0.000 & TRUE \\
\hline 2015 & 243.62 & 3.84 & 0.000 & TRUE \\
\hline
\end{tabular}




\begin{tabular}{|c|c|c|c|c|c|c|c|c|c|}
\hline \multicolumn{1}{|c|}{ AHE RESULTS OF ARMA (1,1) AND GARCH (1,1) MODELS } \\
\hline \multirow{2}{*}{ Year } & \multicolumn{3}{|c|}{ ARMA (1,1) } & \multicolumn{5}{c|}{ GARCH (1,1) } \\
\cline { 2 - 12 } & $\boldsymbol{\mu}$ & $\boldsymbol{\varphi}_{1}$ & $\boldsymbol{\theta}_{1}$ & $\boldsymbol{\sigma}$ & $\boldsymbol{\mu}$ & $\boldsymbol{\alpha}_{\mathbf{0}}$ & $\boldsymbol{\alpha}_{1}$ & $\boldsymbol{\beta}_{1}$ & $\boldsymbol{\alpha}_{\mathbf{1}}+\boldsymbol{\beta}_{1}$ \\
\hline 2011 & 1313.23 & 0.000 & 0.000 & 107.43 & 1313.23 & 318560.78 & 0.41 & 0.41 & 0.82 \\
\hline 2012 & 1110.03 & 0.000 & 0.000 & 38.36 & 1110.03 & 10750.03 & 0.50 & 0.50 & 0.99 \\
\hline 2013 & 1156.93 & 0.000 & 0.000 & 51.17 & 1156.93 & 5353.35 & 0.50 & 0.50 & 0.99 \\
\hline 2014 & 1414.83 & 0.000 & 0.000 & 62.44 & 1414.83 & 0.00 & 0.50 & 0.50 & 1.00 \\
\hline 2015 & 1346.97 & 0.000 & 0.000 & 82.80 & 1346.97 & 12268.11 & 0.50 & 0.50 & 0.99 \\
\hline
\end{tabular}

Moving-Average (ARMA) models form a class of linear time series models that helps to detect time varying phenomenon in the conditional volatility.

Table 5 presents the results of ARMA $(1,1)$ and GARCH $(1,1)$ models. The $\phi_{1}$ parameters in the mean equation are significant for all the years. The null hypothesis that the exogenous variable in the mean equation for GARCH model is significantly different from zero for these periods is rejected. The sum of $\operatorname{ARCH}(1,1)$ and GARCH $(1,1)$ is 1 in year 2014 and very close to 1 for the other years. This indicates that the observed price series are highly volatile. Thus, null hypothesis that there is none volatility clustering in observed price series is rejected. The GARCH $(1,1)$ model result shows that there is an arbitrage opportunity and extreme mispricing in the Bahrain stock market.

Autocorrelation test measures the relationship between the values of a random variable at time $t$ and its value in the previous period. This is used to test the dependence/independence of random variables in an observed price series. The test is performed by taking 12 lags of the daily log return of the Bahrain index. The result of autocorrelation and partial autocorrelation is presented in table 6 . The autocorrelation values for the year 2011 ranges from negative value of 0.045 to a high positive value of 0.806 in lag 1. This indicates that there is independence of random variables in observed price series. The years 2012 to 2015 displays high positive correlation in the lagged values. This signals that the market is inefficient in the weak form.

\section{Efficient Market Hypothesis and Hurst Index}

The basic idea of the Efficient Market Hypothesis is that the price variations follow a random walk (Bachelier).The random walk hypothesis is a financial theory stating that stock prices follow a random process and there are not predictable. From the mathematical point of view, the random walk is given by the equation: $P_{t}=P_{t-1}+\varepsilon$ where $\varepsilon$ is a white noise $(W N) \sim\left(0, \sigma^{t} 2\right)$, while the value attended of the equation of which above it is equal to $P_{t-1}$. The Brownian motion $(\mathrm{Bm})$ is the extension of the random walk in continuous time (De Moivre Laplace Central Limit Theorem). From the studies of Fame and those of Sharpe, the conclusion can be drawn that the evolution of the price of a financial tool is essentially casual and therefore the movements of the same (and also of the outputs) don't follow any regularity but they would follow a trial stochastic. In fact, prices move second a Levy's process (Levy 1948). It is

\begin{tabular}{|c|c|c|c|c|c|c|c|c|c|c|}
\hline \multicolumn{10}{|c|}{ CORRELOGRAM ANALYSIS } \\
\hline \multirow{2}{*}{ Lag } & \multicolumn{2}{|c|}{2011} & \multicolumn{2}{c|}{$\mathbf{2 0 1 2}$} & \multicolumn{2}{c|}{$\mathbf{2 0 1 3}$} & \multicolumn{2}{c|}{$\mathbf{2 0 1 4}$} & \multicolumn{2}{c|}{$\mathbf{2 0 1 5}$} \\
\cline { 2 - 13 } & ACF & PACF & ACF & PACF & ACF & PACF & ACF & PACF & ACF & PACF \\
\hline 1 & 0.806 & 0.813 & 0.990 & 0.995 & 0.982 & 0.995 & 0.980 & 0.980 & 0.991 & 1.001 \\
\hline 2 & 0.605 & -0.123 & 0.981 & 0.060 & 0.967 & 0.062 & 0.958 & -0.156 & 0.981 & 0.002 \\
\hline 3 & 0.392 & -0.162 & 0.972 & 0.014 & 0.952 & -0.077 & 0.936 & -0.059 & 0.970 & -0.026 \\
\hline 4 & 0.173 & -0.169 & 0.961 & 0.046 & 0.935 & -0.076 & 0.913 & -0.049 & 0.959 & 0.008 \\
\hline 5 & -0.045 & -0.185 & 0.949 & 0.051 & 0.920 & -0.061 & 0.892 & 0.081 & 0.948 & 0.003 \\
\hline 6 & -0.223 & -0.118 & 0.939 & 0.048 & 0.905 & -0.148 & 0.871 & -0.019 & 0.936 & -0.005 \\
\hline 7 & -0.362 & -0.110 & 0.928 & 0.063 & 0.891 & 0.096 & 0.849 & -0.014 & 0.924 & -0.005 \\
\hline 8 & -0.475 & -0.170 & 0.917 & 0.042 & 0.877 & 0.016 & 0.829 & 0.019 & 0.912 & 0.048 \\
\hline 9 & -0.531 & -0.094 & 0.907 & -0.003 & 0.864 & 0.041 & 0.809 & -0.022 & 0.900 & 0.108 \\
\hline 10 & -0.567 & -0.193 & 0.899 & 0.105 & 0.850 & -0.067 & 0.787 & -0.065 & 0.888 & 0.049 \\
\hline 11 & -0.571 & -0.179 & 0.888 & -0.043 & 0.836 & 0.017 & 0.765 & 0.059 & 0.877 & -0.128 \\
\hline 12 & -0.530 & -0.163 & 0.877 & -0.069 & 0.823 & 0.002 & 0.744 & -0.058 & 0.865 & -0.005 \\
\hline
\end{tabular}


a stochastic process with independent, stationary increments, the most famous Levy's process is the Brownian motion $(\mathrm{Bm})$. The $\mathrm{Bm}$ in the financial markets is compatible, because ensure the randomly of the price changes. This is in perfect tune with the Efficient Market Hypothesis (EMH). The $\mathrm{Bm}$ is more used in the financial literature (EHM, option pricing ...). In continuous time, the standard Brownian Motionis defined by means of the following properties:

- $W(0)=0$

- $W(t)$ is continuos in $t$, with probability 1 ;

- $W(t)$ has stationary and independent increments, $W\left(t_{1}\right)-W(t)$ is independent and form a stationary sequence;

- $W\left(t_{2}\right)-W\left(t_{1}\right) \sim N\left(0, t_{2}-t_{1}\right)$

- Martingale Property;

- Non differentiability of $W(t)$;

- Brownian Motion Standard and the Geometric Bm are a Markov process.

A non-negative variation of the Brownian motion has to be introduced: it is called Geometric Brownian motion (GBm), the GBm ensures no price negativity, given $S(t)$ a price of asset, we have:

$$
\begin{aligned}
S(t) & =S_{0}{ }^{*} \exp (\mu t+\sigma W(t)) ; \\
\log [S(t)] & =S_{0}+\log (\mu t+\sigma W(t)) ; \\
\log (\mu t+\sigma W(t)) & =\log S(t)-\log S(0)=\log \frac{S_{t}}{S_{0}}
\end{aligned}
$$

where $\mu$ is the drift, $\sigma-$ the coefficient of dispersion, $W(t)$ - the Bm.

The covariance of the $\mathrm{Bm}$ is:

$$
\begin{aligned}
& \operatorname{cov}(B(t), B(s)) \text { for each } s, t \geq 0 ; \\
& \operatorname{cov}(B(t), B(s))=E(B(t) B(s))=\min (t, s)
\end{aligned}
$$

The Brownian geometrics' motion is used for three fundamental aspects:

- It excludes the negativity of the prices.

- It is conforming to the hypothesis of the principle of arbitrage (compatible with EMH).

- The SDE is resolvable through the Ito's lemma.

The fractional Brownian motion (fBm), is a generalization of Bm. Unlike classical Brownian motion, the increments of fBm do not need be independent. The covariance of this motion is:

$$
E\left[B^{H}(t) B^{H}(s)\right]=\frac{1}{2}\left(t^{2 H}+s^{2 H}-|t-s|^{2 H}\right)
$$

where $H$ is a real number in $(0,1)$, called the Hurst index or Hurst parameter associated with the fractional Brownian motion. The Hurst exponent describes the raggedness of the resultant motion. The value of $H$ determines what kind of process the $\mathrm{fBm}$ is:

- if $H=1 / 2$ then the process is in fact a Brownian motion (random process compatible with EMH);

- if $H>1 / 2$ then the increments of the process are positively correlated;

- if $H<1 / 2$ then the increments of the process are negatively correlated.

Also, we estimated the Hurst Index, with R/S (Rescaled Range) method, according to the
Brownian motion Theory when the markets are efficient the Hurst Index is 0.5 . R/S method was introduced by Harold Hurst, interested in determining the optimum dam sizing for the Nile river, he observed that the flow of water (random variable) exhibited some form of dependence. For a set of observations $\left(X_{i}\right)$, we define $Y_{n}$ and $\sigma^{2}$ as the partial sum and the sample variance, subsequently the Rescaled Range is:

$$
R / S=\frac{1}{\sigma_{n}}\left[\max \left(Y_{i}-\frac{i}{n} Y_{n}\right)-\min \left(Y_{i}-\frac{i}{n} Y_{n}\right)\right]
$$

Hurst identified the following relation: $E(R / S) \sim C_{2}{ }^{*} n^{H}$; where $H$ is the Hurst exponent and $c$ is finite, independent of $n$. The graphical approach consists in: $\log (R / S)=\log c_{2}+H^{*} \log n$; note that $H$ is the slope of the regression.

\section{CONCLUSIONS}

The current study examines the weak form efficiency of the Bahrain stock market. The study period is from 2011 to 2015 . The weak form efficiency of the market is tested using runs test, autocorrelation test, $\mathrm{ARCH}$ and GARCH $(1,1)$ models. The study reports that the Bahrain stock market does not follow normal distribution and the successive price changes are not independent. Further, $\mathrm{ARCH}$ effect is significant and indicative of a time-varying conditional volatility. There is an arbitrage opportunity and extreme mispricing in the Bahrain stock market as indicated by the GARCH $(1,1)$ model. High positive correlation is observed in the price series. All the above results indicate that the Bahrain stock market is inefficient in its weak form. In fact, the results of the Hurst exponent confirm the inefficient of the market, the index for the period (2011-2015) is 0.61. The dependence of the events (log-returns) is called Long Range. In this case it is more likely that a positive(negative) trend is followed by another positive (negative), in other words in the Bahrain stock market time series there is a persistence (this result is consistent with the high positive correlation). Regarding the Hurst index, the estimate obtained with R/S method is very variable. The Hurst index estimator varies with the size of the sample of observations.

Many authors propose other method (Wavelet, $A M B E)$. The dependence of the price variations and the value of the Hurst Index give us an idea of the persistence of the time series. In fact, how to show before, the market is not randomly, and there is an arbitrage opportunity through the strategies based on market trends (negatively or positively). This result is consistent with those reported in past studies [16, 18, 19]. A variety of previous empirical studies have confirmed the inefficiency of other emerging stock markets [31-34]. The inefficiency suggests that the investors have good opportunities to gain abnormal profits from analysis of the past prices through the individuation of the trends (bullish or bearish). Even if, the EMH remains one of the best famous theory in the financial topics, there are many factors that 
depart the market from efficiency. In particular, the individuals do not have the same set of information about the stock, and they are not fully rational how to speculate in the Neoclassical theories (CAPM, Markowitz diversificatio and so on). These aspects have led to the emergence of new the approach „behavioural finance” with Kahnmean and Tversky (Prospect Theory). Ejaz et al. [35] suggested that emerging stock markets such as Bahrain Bourse offer a much wider range of portfolio diversification opportunities compared to developed stock markets.

\section{ACKNOWLEDGMENTS}

This work was supported by the grant POCU 380/6/13/ 123990, co-financed by the European Social Fund within the Sectorial Operational Program Human Capital 2014-2020.

\section{REFERENCES}

[1] Samuelson, P.A., Proof that properly anticipated prices fluctuate randomly, In: Industrial Management Review, 1965, 6, 2, 41-49

[2] Fama, E.F., Efficient Capital Markets: A Review of Theory and Empirical Work, Journal of Finance, 1970, 25(2), 383-417.

[3] Iqbal, T.H., Mallikarjunappa, T., Efficiency of Stock Market: A Study of Stock Price Responses to Earnings Announcements. LAP Lambert Academic Publishing Company, 2011, Germany.

[4] Ananzeh, I.E., Testing the Weak Form of Efficient Market Hypothesis: Empirical Evidence from Jordan, International Business and Management, 2014, 9, 2, 119-123

[5] Chan, K.C., Gup, B.E., Pan, M.-S., An Empirical Analysis of Stock Prices in Major Asian Markets and the United States, In: The Financial Review, 1992, 27, 2, 289-307

[6] Lo, A.W., MacKinlay, A.C., Stock market prices do not follow random walks: Evidence from a simple specification test, In: The Review of Financial Studies, 1988, 1, 1, 41-66

[7] Iqbal, T.H., Mallikarjunappa, T., A Study of Efficiency of the Indian Stock Market, In: Indian Journal of Finance, 2010, $4,5,32-38$

[8] Iqbal, T.H., Mallikarjunappa, T., An Empirical Testing of Semi-Strong Form Efficiency of Indian Stock Market, In: The Journal of Amity Business School, 2008, 9, 1, 24-33

[9] Dahel, R., Laabas, B., The Behaviour of Stock Prices in the GCC Markets, In: Journal of Development \& Economic Policies, 1999, 1, 89-105

[10] Abeysekera, S.P., Efficient Markets Hypothesis and the Emerging Capital market in Sri Lanka: Evidence from the Colombo Stock Exchange - A Note, In: Journal of Business Finance and Accounting, 2001, 28, 1, 249-261

[11] Abraham, A., Seyyed, F.j., Alsakran, S.A., Testing the Random Walk Behavior and Efficiency of the Gulf Stock Markets, In: The Financial Review, 2002, 37, 3, 469-480

[12] Rao, D.N., Shankaraiah, K., Stock Market Efficiency and Strategies for Developing GCC Financial Markets: A Case Study of the Bahrain Stock Market, In: The Arab Bank Review, 2003, 5, 2, 16-21

[13] Moustafa, M.A., Testing the Weak-Form Efficiency of the United Arab Emirates Stock Market, In: International Journal of Business, 2004, 9, 3, 309-325

[14] Sharma, S.N., On the non-normality of GCC Stock Markets, In: The ICFAI Journal of Applied Corporate Finance, 2005, 51-58

[15] Elango, R., Hussein, M. I., An Empirical Analysis on the Weak-Form Efficiency of the GCC Markets Applying Selected Statistical Tests, November 2007, Available at: Social Science Research Network https://papers.ssrn.com/ sol3/papers.cfm?abstract_id=1026569 [Accesed January 19, 2017]

[16] Smith, G., Random Walks in Middle Eastern stock markets, In: Applied Financial Economics, 2007, 17, 7, 587-596

[17] Asiri, B.K., Testing Weak from Efficiency in the Bahrain Stock Market, In: International Journal of Emerging Markets, 2008, 3, 1, 38-55

[18] Al Kharausi, S., Weaglay, R.O., Weak Form Market Efficiency during the 2008 Financial Crisis: Evidence from The Muscat Securities Market, In: The International Journal of Business and Finance Research, 2014, 8, 4, 27-42

[19] Awan, U.F., Subayyal, M., Social Science Research Network, 2016

[20] Sharma, J.L., Kennedy, R.E., A comparative Analysis of Stock Price Behaviour on the Bombay, London, and New York Stock Exchanges, In: Journal of Financial and Quantitative Analysis, 1977, 391-413

[21] Karemera, D., Ojah, K., Cole, j.A., Random Walks and Market Efficiency Tests: Evidence from Emerging Equity Markets, In: Review of Quantitative Finance and Accounting, 1999, 13, 171-188

[22] Mookerjee, R., Yu, Q. An Empirical Ananlysis of the Equity Markets in China, In: Review of Financial Economics, 1999, 8, 41-60

[23] Groenewold, N., Sam, T., Wu, Y., The Efficiency of the Chinese Stock Market and the Role of the Banks, In: Journal of Asian Economics, 2003, 14, 593-609

[24] Seddighi, H.R., Nian, W., The Chinese Stock Exchange Market: Operations and Efficiency, In: Applied Financial Economics, 2004, 14, 785-797

[25] Engle, R., Autoregressive Conditional Heteroscedasticity with Estimates of the Variance of UK Inflation, In: Econometrica, 1982, 50, 4, 987-1008 
[26] Bollerslev, T., Generalised Autoregressive Conditional Heteroscedasticity, In: Journal of Econometrics, 1986, 51, 307-327

[27] Gharaibeh, A., Hammadi, F., The Day of the Week Anomaly in Bahrain's Stock Market, In: International Management Review, 2013, 9, 2, 60-69

[28] Hawaldar, I.T., The Cross-Sectional Variation in Portfolio Returns: Evidence from Bahrain Bourse, In: British Journal of Economics, Finance and Management Sciences, 2016, 12, 2, 1-11

[29] Hawaldar, I.T., The Reaction of Bahrain Bourse to Announcement of Annual Financial Results, In: International Review of Business Research Papers, 2016, 12, 1, 64-75

[30] Hawaldar, I.T., Shakila, B., Pinto, P., Empirical Testing of Month of the Year Effect on Selected Commercial Banks and Services Sector Companies Listed on Bahrain Bourse, In: International Journal of Economics and Financial Issues, 2017, 7, 2, 426-436

[31] Spulbar, C., Birau, R., Testing weak-form efficiency and long-term causality of the R.I.P.H emerging capital markets, In: International Journal of Business Quantitative Economics and Applied Management Research, 2018, 5, 2, 1-19

[32] Pinto, P., Hawaldar, I.T, Guruprasad, K., Rohit, B., Spulbar, C., Birau, R., Stanciu, C.V., The Impact of Risk Anomalies on the Pharmaceutical Sector of the Indian Stock Market - A Comparative Analysis between Pharmaceutical, FMCG and IT companies, In: Revista de Chimie, 2020, 71, 2, 58-63

[33] Spulbar, C., Birau, R., Emerging Research on Monetary Policy, Banking, and Financial Markets, IGI Global USA (formerly Idea Group Inc.), 2019, 322, ISBN13: 9781522592693, ISBN10: 1522592695, EISBN13: 9781522592716, https://doi.org/10.4018/978-1-5225-9269-3

[34] Spulbar, C., Ejaz, A., Birau, R., Trivedi, J., Sustainable Investing Based on Momentum Strategies in Emerging Stock Markets: A Case Study for Bombay Stock Exchange (BSE) of India, In: Scientific Annals of Economics and Business, 2019, XX (X), 1-11 (tbd), https://doi.org/10.2478/saeb-2019-0029

[35] Ejaz, A., Birau, R., Spulbar, C., Buda, R., Tenea, A.C., The impact of domestic portfolio diversification strategies in Toronto stock exchange on Canadian textile manufacturing industry, Industria Textila, 2020, 71, 3, 215-222, http://doi.org/10.35530/IT.071.02.1696

\section{Authors:}

THONSE HAWALDAR IQBAL ${ }^{1}$, RAMONA BIRAU ${ }^{2}$, CRISTI SPULBAR ${ }^{3}$, BABITHA ROHIT ${ }^{4}$, PRAKASH PINTO ${ }^{4}$, THEKKEKUTT MATHUKUTTI RAJESHA ${ }^{5}$, FABRIZIO DI SCIORIO 6

${ }^{1}$ College of Business Administration, Kingdom University, Bahrain e-mail: thiqbal34@gmail.com;

${ }^{2}$ Faculty of Education Science, Law and Public Administration, Constantin Brancusi University of Targu Jiu, Romania 3University of Craiova, Faculty of Economics and Business Administration, Craiova, Romania e-mail: cristispulbar7@gmail.com

${ }^{4}$ St. Joseph Engineering College, Vamanjoor, India e-mail: babitha.rk2002@gmail.com, prakashpinto74@gmail.com

${ }^{5}$ Accreditation \& Quality Assurance Office, Kingdom University, Bahrain e-mail: r.mathukutti@ku.edu.bh

6University of Campania Luigi Vanvitelli, Caserta, Italy e-mail: fabriziodisciorio@hotmail.com

Corresponding author:

RAMONA BIRAU

e-mail: ramona.f.birau@gmail.com 